\title{
Room-Temperature Flexure Fixture for Advanced Ceramics
}

\author{
George D. Quinn \\ U.S. DEPARTMENT OF COMMERCE \\ Technology Administration \\ National Institute of Standards \\ and Technology \\ Ceramics Division \\ Gaithersburg, MD 20899
}

NLT 



\title{
Room-Temperature Flexure Fixture for Advanced Ceramics
}

\section{George D. Quinn}

\author{
U.S. DEPARTMENT OF COMMERCE \\ Technology Administration \\ National Institute of Standards \\ and Technology \\ Ceramics Division \\ Gaithersburg, MD 20899
}

August 1992

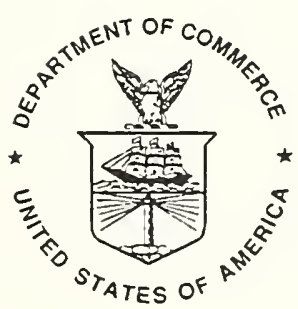

U.S. DEPARTMENT OF COMMERCE Barbara Hackman Franklin, Secretary

TECHNOLOGY ADMINISTRATION

Robert M. White, Under Secretary for Technology

NATIONAL INSTITUTE OF STANDARDS

AND TECHNOLOGY

John W. Lyons, Director 

ROOM-TEMPERATURE FLEXURE FIXTURE FOR ADVANCED CERAMICS

George Quinn

Ceramics Division

\section{ABSTRACT}

A test fixture for the measurement of the flexure strength of advanced ceramic specimens is presented. The fixture meets the requirements of several American and international standards.

\section{INTRODUCTION}

This report presents a four-point flexure fixture that is in accordance with the requirements of U.S. Army MII STD 1942 [1] and ASTM C 1161 [2]. These standards prescribe specific specimen and fixture sizes, tolerances, and alignment requirements. The standards specify that the fixture must have sufficient articulation to ensure even line-loading onto the specimen surface and equal loading at the four loading pins. Machined specimens will usually meet the parallelism specifications and therefore may be tested with a simple semi-articulating fixture. A fullyarticulating fixture is not necessary. As-fired specimens can even be used with the fixture in some instances [3].

Many fixture designs have emphasized unnecessarily the need to have full articulation. This is usually done at the cost of having fixed-load bearing pins, or simple slots into which the load pins rest. The latter are not reliable for ensuring that load pins will roll since the rollers may rest against either shoulder of the slot. Both schemes can cause frictional constraints as the specimen is loaded and will cause significant experimental error $[4,5]$.

C 1161 and MIL STD 1942 show several general schematics of possible fixture designs. A variety of design will meet the requirments of the standards. This report shows one successful design for the three- and four-point "B" sizes specified in the standards. The fixture has been shown previously in Reference [3] which summarized results of a successful four nation round-robin exercise.

The fixture is designed so that it can be set up and aligned easily and quickly ( -30 minutes). The alignment system is quite simple and relies upon the use of a single $6.35 \mathrm{~mm}$ (1/4 inch) locating hole or pin in each part. (An alternate diameter could also be used provided that all parts are adjusted accordingly.) This will ensure that the fixtures are aligned properly from left to right, and from front to back. The set up procedure is given in Appendix A.

The fixture shown in this report is intended for use with flat and parallel specimens. If specimens are twisted or warped, then a 


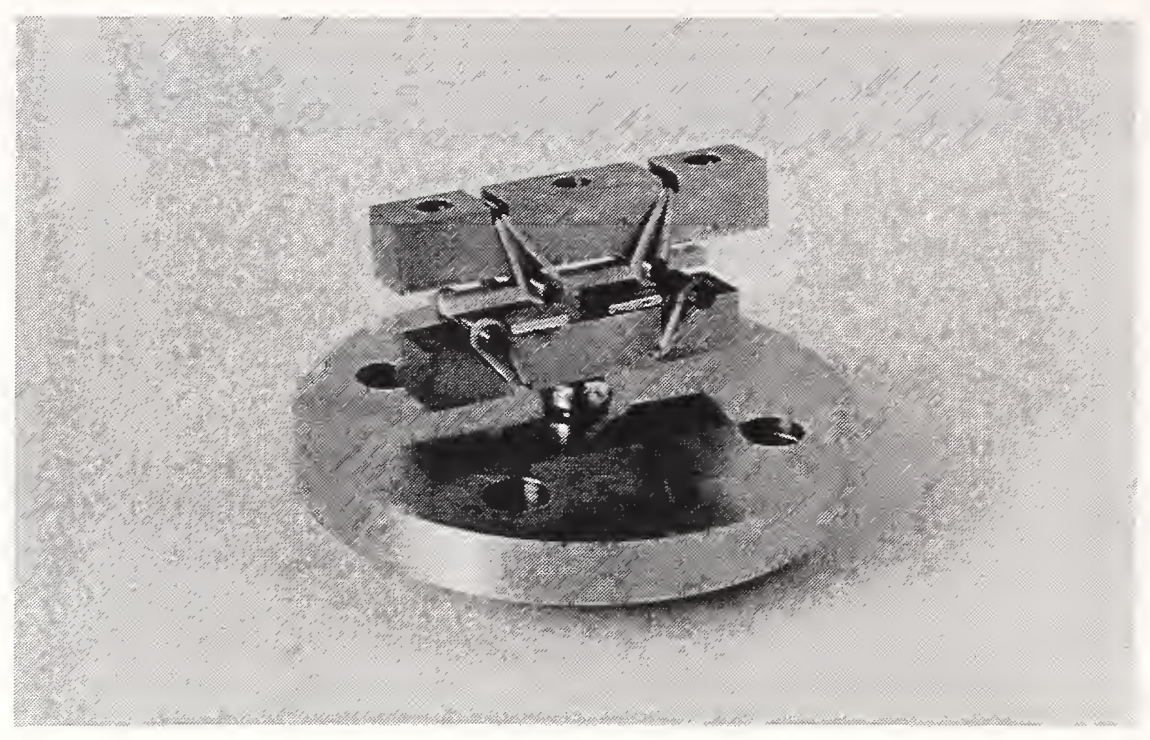

Figure 1 The four-point flexure fixture with an alumina specimen in place.

\section{4-PT FLEXURE FIXTURE \\ CONFIGURATION B \\ FOR $4.5 \mathrm{~mm}$ ROLLERS}

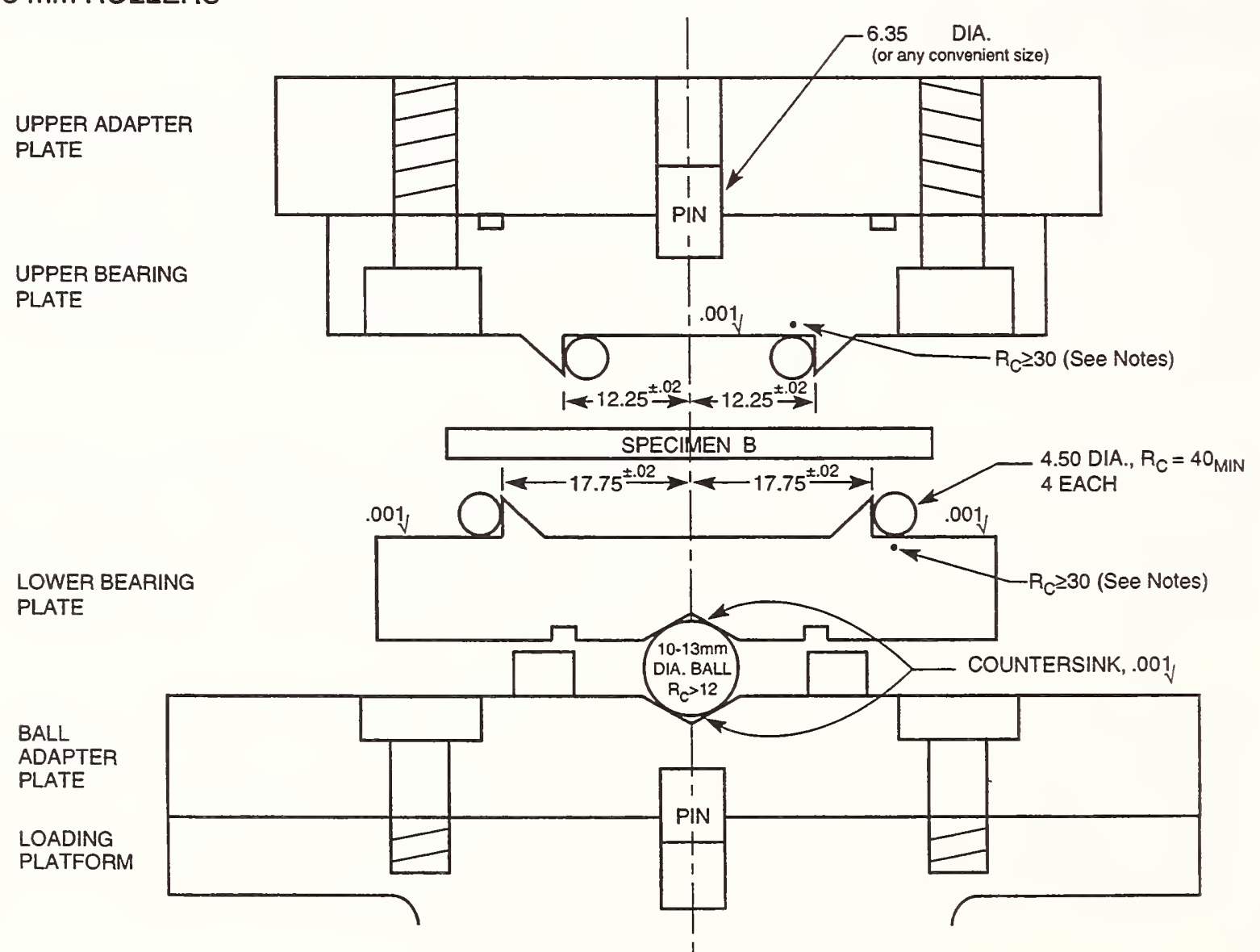

Figure 2 An assembly drawing for the fixture. All dimensions in mm. 
fully-articulating fixture is necessary. References [6] and [7] give designs for fully-articulating fixtures which also have rolling-loading pins.

\section{FIEXURE FIXTURE}

Figures 1 and 2 illustrate the fixture with a specimen in place. The fixture is for size B specimens ( $3 \times 4 \times 45-50 \mathrm{~mm}$ ) that are flat and parallel within the specification of ASTM C 1161 and MIL STD 1942. The adaptor plates will vary with the testing machine. one (not shown below) is needed to attach the upper bearing plate to the crosshead. Another is needed to attach the lower bearing plate to the load cell (or a platform attached to the load cell such as shown later).

The following parts are illustrated as Figures 3-6:

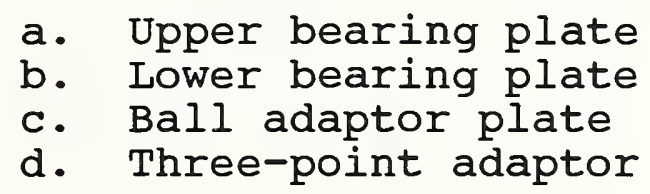

The first two should be made of a steel that is sufficiently hard to resist plastic deformation at the ball seat and the points where the loading rollers contact them. A Rockwell C $\left(R_{C}\right)$ hardness of 30 or higher is required and will permit testing flexural specimens with strengths up to $3000 \mathrm{MPa}$. Maraging $18-250$ or $18-300$ steels* are quite good since they have this hardness in the annealed state (and will not require a heat treatment), are quite machinable, and are oxidation resistant. An alternative is wrought stainless steel, grades 17-4 PH (AISI \#630), PH 13-8 Mo, or 15-5 $\mathrm{PH}^{* *}$. These have $R_{C}=30-32$ in the solution treated state. The Maraging or wrought stainless steels can be obtained from a tool steel supplier. Note that most common stainless steels are relatively soft and are not satisfactory to sustain the concentrated Hertzian contact loads.

The three-point adaptor and the ball adaptor plate can be made of any grade steel with $R_{C}>12$ since Hertzian stresses are smaller in these parts. Common stainless steels (such as a 316 grade) are adequate. The ball adaptor plate is designed to either attach directly to the load cell or to a platform which is attached to the load cell. On one side it has a $6.35 \mathrm{~mm}(1 / 4 \mathrm{inch})$ hole for alignment and centering purposes. On the other side it has a countersink to hold and center the ball. The countersink and the centering hole must be well aligned with respect to each other.

* VAscomax steel. Co. An 18 \% nickel steel. The second number refers to the yield stress in ksi. The identification of materials in this report does not imply an endorsement by the National Institute of standards and Technology

* * ARMCO Steel. 


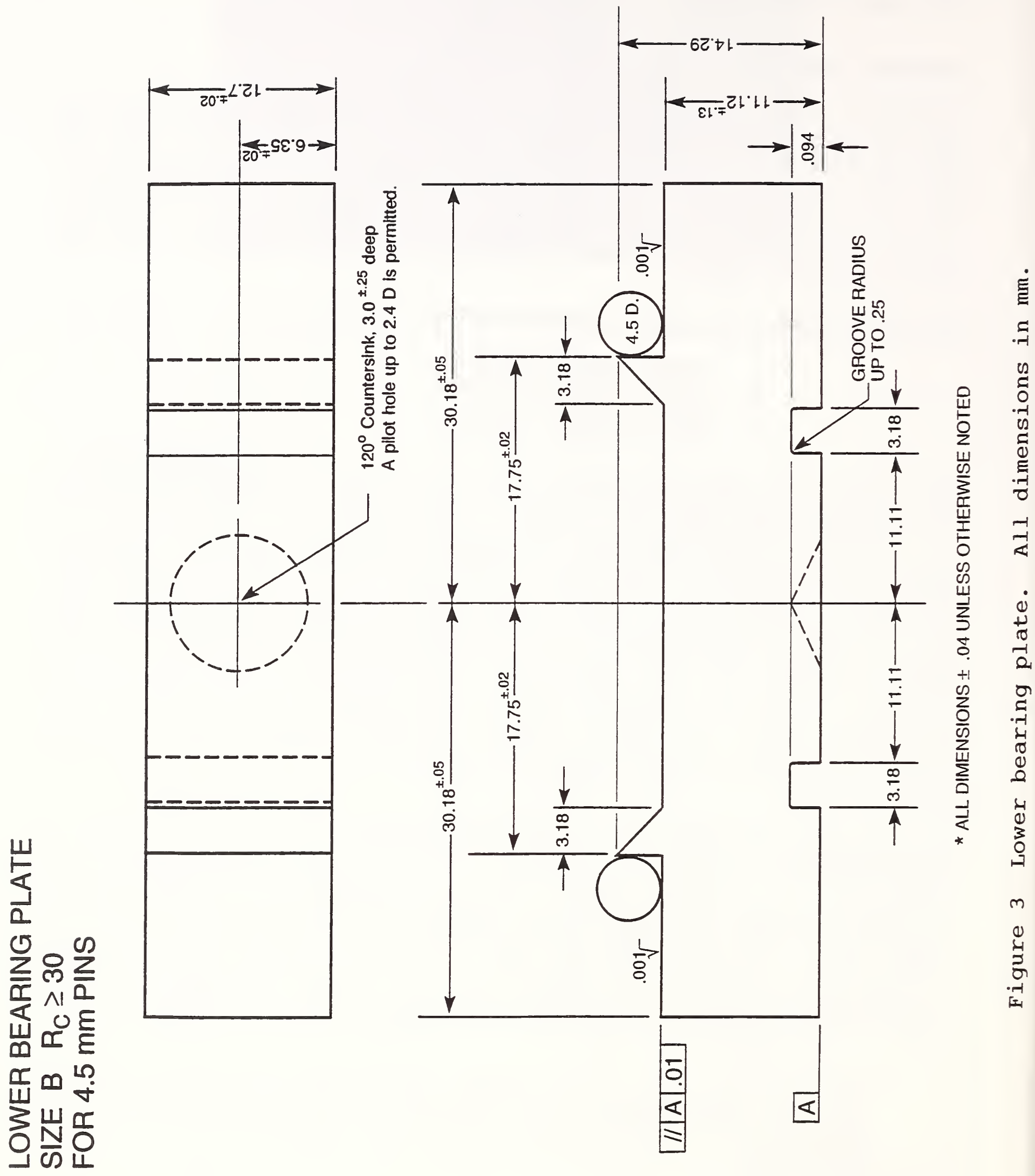




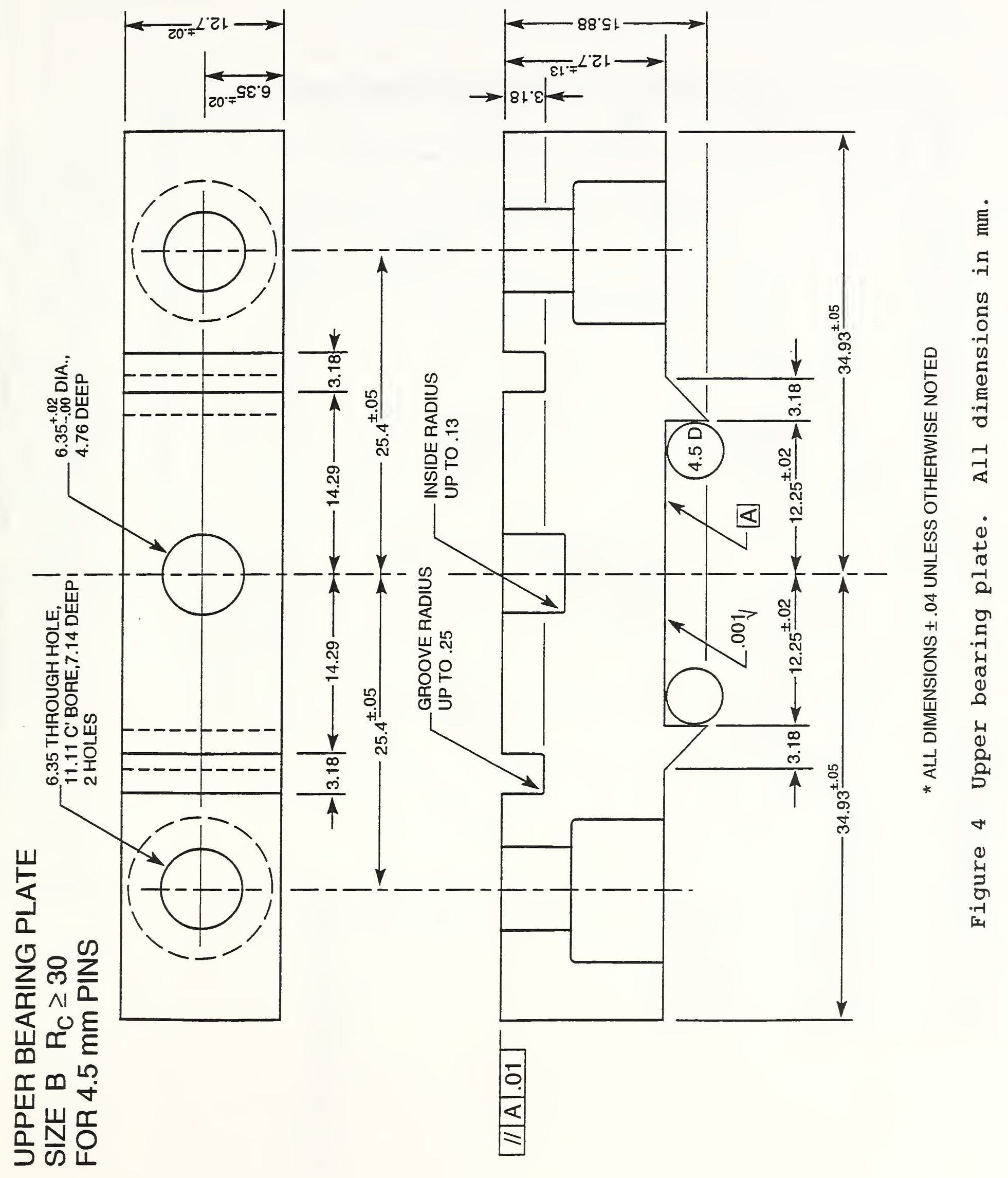









\section{Three Point Adaptor Size B}


$R_{C}>12$

Figure 6 Three-point adaptor which is inserted into the upper bearing plate. All dimensions in $\mathrm{mm}$. 
It is important that the adaptor plates have sufficient play so that their position can be adjusted. Their mounting holes should have ample clearance for the mounting bolts. For example, Figure 5 shows four mounting holes of $7.14 \mathrm{~mm}$ diameter which are intended to be used with $6.35 \mathrm{~mm}$ diameter socket head bolts.

The adaptor plates must be able to align the upper and lower flexure fixture pieces. The whole system is easily aligned by the use of $6.35 \mathrm{~mm}$ (1/4 inch) diameter holes and locating pins in each part as shown in Figure 2. A long $6.35 \mathrm{~mm}$ ( $1 / 4$ inch) diameter rod is used to initially align the system during setup.

The fixture is designed to be used with loading rollers (bearings) that are $4.5 \mathrm{~mm}$ in diameter that are about $25 \mathrm{~mm}$ long. * They should have a hardness of $R_{C} 40$ or higher. Hardened dowel pins have hardnesses at least as high as this and are as high as $R_{C} 60$. Rubber bands are needed to hold the rollers against the shoulders. The rubber bands should be \#12 size and are available from any stationery or office supply store. Smaller bands will be too tight; larger ones, too loose.

A $\sim 10 \mathrm{~mm}$ diameter steel ball is also needed. The exact diameter is not important. It need only have a hardness of about $R_{c} 12$, but chrome steel balls of $R_{c} 60$ are readily available off-the-shelf. A $13 \mathrm{~mm}$ diameter ball could be used, but doesn't articulate as well.

Wood or aluminum shims can be inserted under the fixture, so that when the specimen breaks, the lower bearing plate will not topple off the ball. This facilitates setting up the next specimen.

The lower bearing plate can rotate around the vertical axis such that the loading rollers are not parallel. A little homemade guide block can be made and afixed with epoxy glue to fixture base to restrict this unwanted rotation.

Fixtures of this type with adaptors have been prepared at costs ranging from $\$ 2000-\$ 3000$.

\section{CONCIUSIONS}

A simple fixture for measuring the flexure strength of advanced ceramics is presented. It is a semi-articulating design for flat and parallel specimens. The fixture meets the requirements of several standard test methods, and when used in accordance with these standards, will measure flexure strengths accurate to within approximately 1\% [4].

* Alternate diameter rollers are satisfactory, except the location of the shoulders in the bearing plates, Figures 3 and 4 , must be revised accordingly. C-1161 and MIL STD 1942 specify that the roller diameter shall be approximately $4.5 \mathrm{~mm}$. 


\section{ACROWLEDGEMENT}

Partial support for this project was provided by the Ceramic Technology Project, U. S. Department of Energy, office of Transportation Technologies, under contract DE-AC05-840R21400 with Martin Marietta Energy Systems, Inc.

\section{REFERENCES}

1. MIL STD 1942 (MR) and MIL STD 1942 (A), "Flexural Strength of High Performance Ceramics at Ambient Temperature, "Avail. from Standardizaion Documents, Order Desk, Bldg. 4, Section D, 700 Robbins Ave., Philadelphia, PA 19111-5094. (The A version is an 1990 update to the earlier MR version.)

2. C-1161-90, "Standard Test Method for Flexural Strength of Advanced Ceramics at Ambient Temperature," Annual Book of ASTM Standards, Vol. 15.01, ASTM, Philadelphia, PA.

3. G. D. Quinn, "Flexure Strength of Advanced Structural Ceramics: A Round Robin." J. Am. Ceram. Soc., Vol. 73, [8] (1990) 2374-84.

4. F.I. Baratta, G. D. Quinn, and W. T. Matthews, "Errors Associated With Flexure Testing of Brittle Materials," U. S. Army MTL Technical Report, TR 87-35, July 1987.

5. G. Quinn, "Twisting and Friction Errors in Flexure Testing," Ceram. Eng. and Sci. Proc., July-Aug. (1992) 319-330.

6. R. G. Hoagland, C. W. Marschall, and W. H. Duckworth, J. Am. Ceram. Soc., Vol. 59, [5-6] (1976) 189-192.

7. U. S. Army MTL "Articulating Flexure Test Fixture," U.S. Patent \#4,941,359, July 17, 1990. (Available from U. S. Army MTL, Watertown, Mass. or G. Quinn, NIST) 


\section{APPENDIX A}

\section{SET UP PROCEDURE}

1. Mount a compression load cell to the base of the test machine. Attach it loosely. See Figure Al.

2. Mount a load cell platform onto the load cell. (This part should have an alignment hole in the middle.)

3. Attach an adaptor plate (of your own design) to the underside of the crosshead. Leave it a bit loose.

(This part must also have an alignment hole.)

4. Pass a rod through the system as shown in Fig. Al. Jiggle the load cell and upper adaptor plates around as necessary to get them into alignment. Bolt the load cell and upper adaptor plates rigidly in position. Check that the rod still passes freely through the holes. The system is now aligned and the four-point fixture pieces can be attached.

5. Attach the ball adaptor plate to the load platform. Fig. A2.

6. Calibrate the load cell.

7. Place a $-10 \mathrm{~mm}$ ball onto the ball adaptor plate. Put the lower bearing plate of the four-point fixture onto the ball. Insert shim blocks (to limit how far the fixture will topple after a specimen fractures).

8. Adjust the load cell balance to read zero.

9. Attach upper bearing plate to the upper adaptor plate.

10. Insert the specimen. Push it as far back onto the loading rollers as necessary, either by using a shim guide, or by the use of prepositioned stops (Not shown).

11. Make sure the lower bearing plate is parallel to the upper bearing plate and has not rotated (about the vertical axis) out of alignment. (A simple guide block (not shown) glued to the back of the assembly can accomplish this.)

12. Preload the specimen slightly.

(No more than $25 \%$ of the projected breakload.)

CAUTION: Make sure the bearings apply load evenly to the specimen, and that there is good line contact at each pin.

The ball will easily tilt so as to allow good left-to-right translation, but the front-to-back articulation is a little more tricky. Jiggle the fixtures as necessary. Hold a flashlight or lamp behind each specimen and look at the roller-specimen contact areas to verify good line loading.

13. On the side of the specimen, lightly mark with pencil the location of the inner two load points. Somehow mark the tension and compression surfaces. Be careful to not misalign the fixture.

13. Put some padding around the specimen to prevent the pieces from flying around too much after breakage. Put a shield around the assembly. (A simple piece of thin transparent plastic will suffice. This is for operator safety, and to preserve and retain fragments for subsequent fractographic analysis.)

14. Perform test. 


\section{ADDITIONAL NOTES}

1. Fragments can sometimes drop into the countersink-ball seat in the ball adaptor plate. This can cause a misalignment. Check the countersink periodically. Clean the fixture after each batch of specimens is broken.

2. The fixture can be easily converted to a three-point fixture by the insertion of the three-point adaptor (Figure 6) into the upper bearing plate as shown in Figure A3. Some caution should be exercised when inserting specimens, however, since the system does not articulate as well as the four-point arrangement. Jiggle the sytem carefully in step 12.

3. The system alternatively can be set up with the load cell attached to the crosshead, provided the correct adaptor plates are available. 




Figure A1 Aligning the system in a universal testing machine. The load cell is on the bottom. A $6.35 \mathrm{~mm}$ (1/4 inch) rod is passed through the entire system to line up the load cell platform and adaptor plate under the crosshead. 


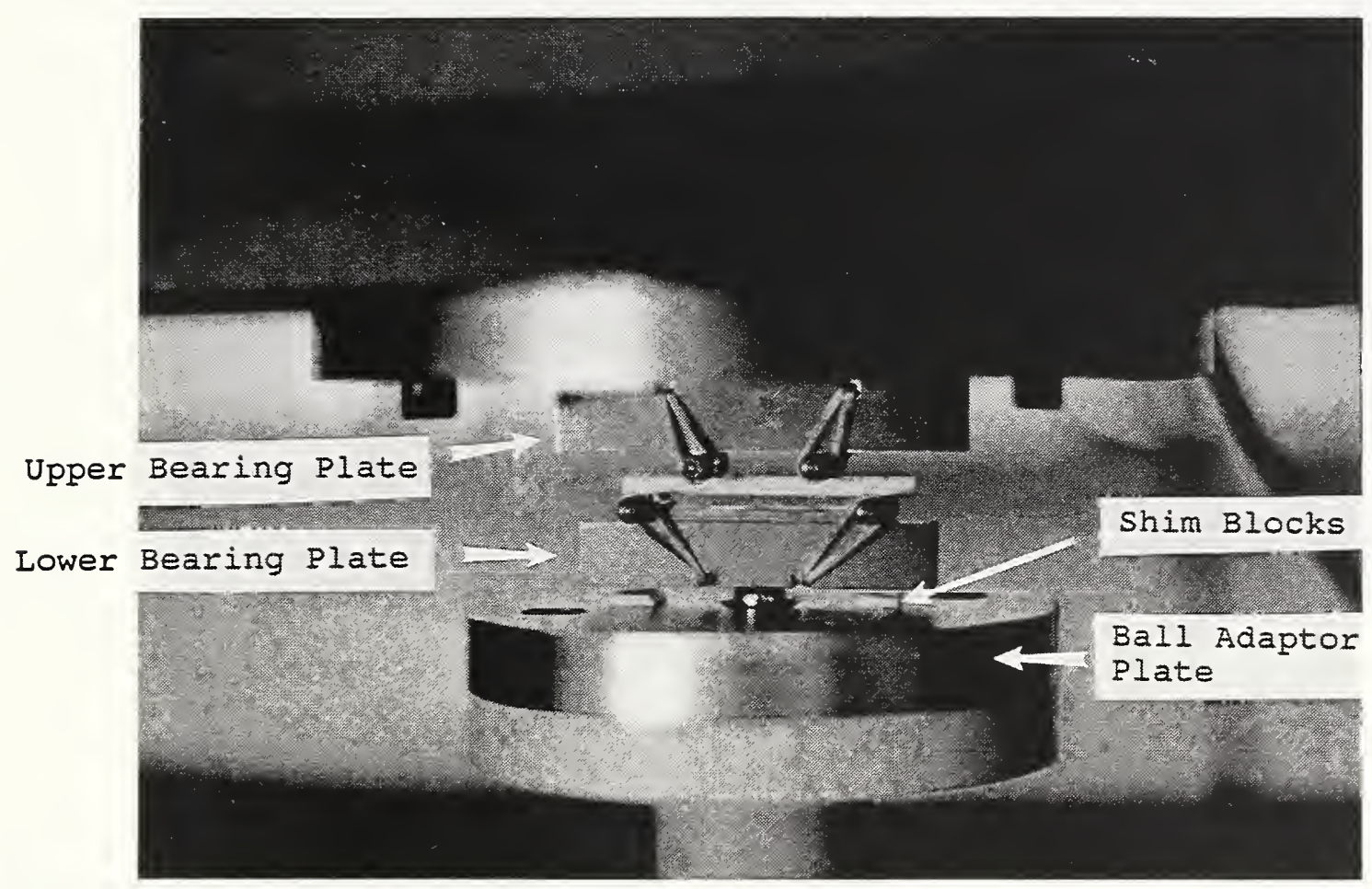

Figure A2 Closeup of the installed fixture. 


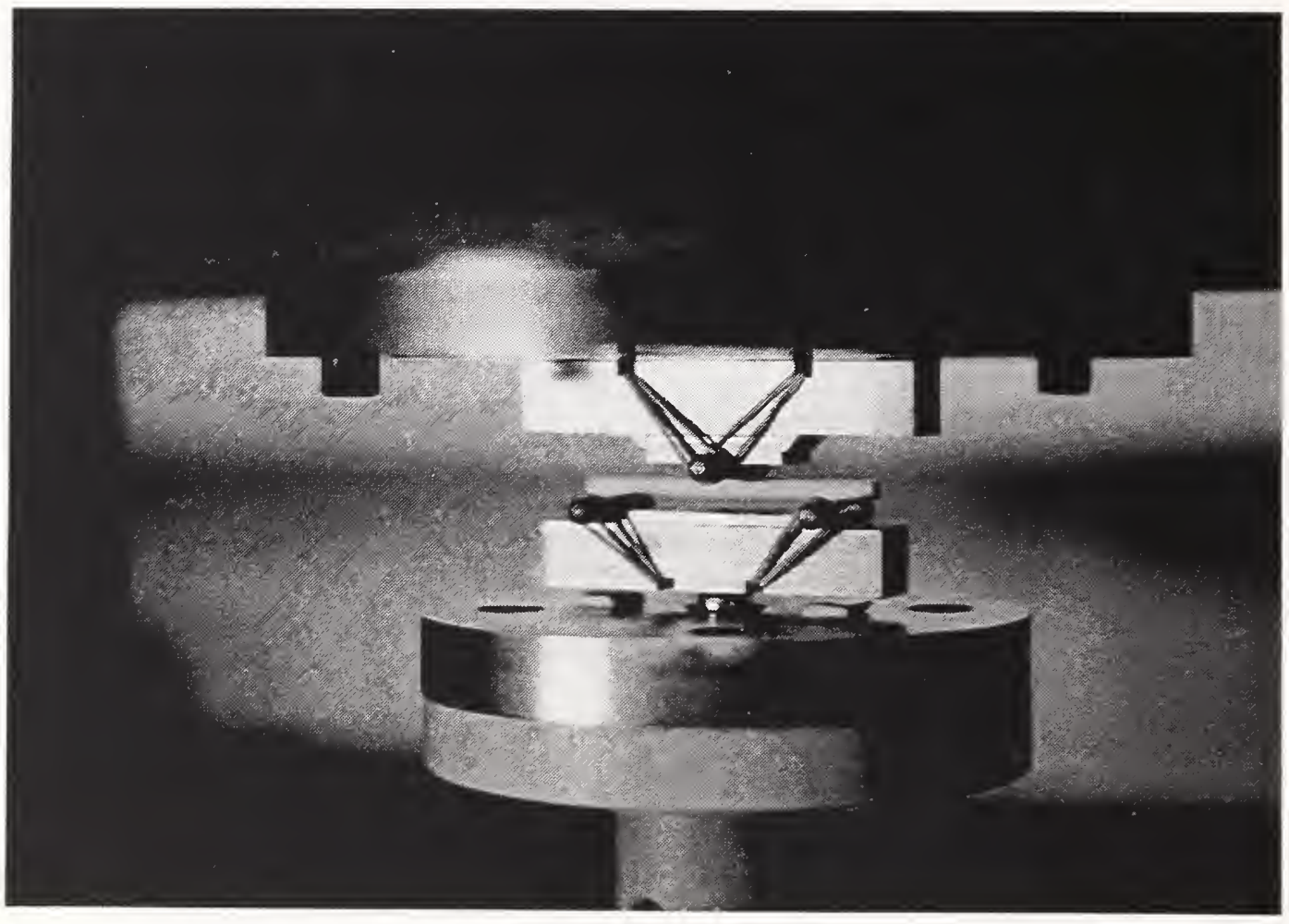

Figure A3 Fixture with three-point adaptor in place. Extra care must be exercised with this arrangement since the fixture does not articulate as well. 


\section{APPENDIX B}

English Equivalent Drawings

For convenience, the following english dimension drawings are furnished. Note that these are designed to be used with $3 / 16$ inch (4.76 mm) diameter loading rollers, and therefore the shoulder dimensions are different than those for the metric drawings which use $4.5 \mathrm{~mm}$ diameter rollers. The drawings and parts are therefore not interchangeable with the metric parts. 




\section{Three Point Adaptor Size B}
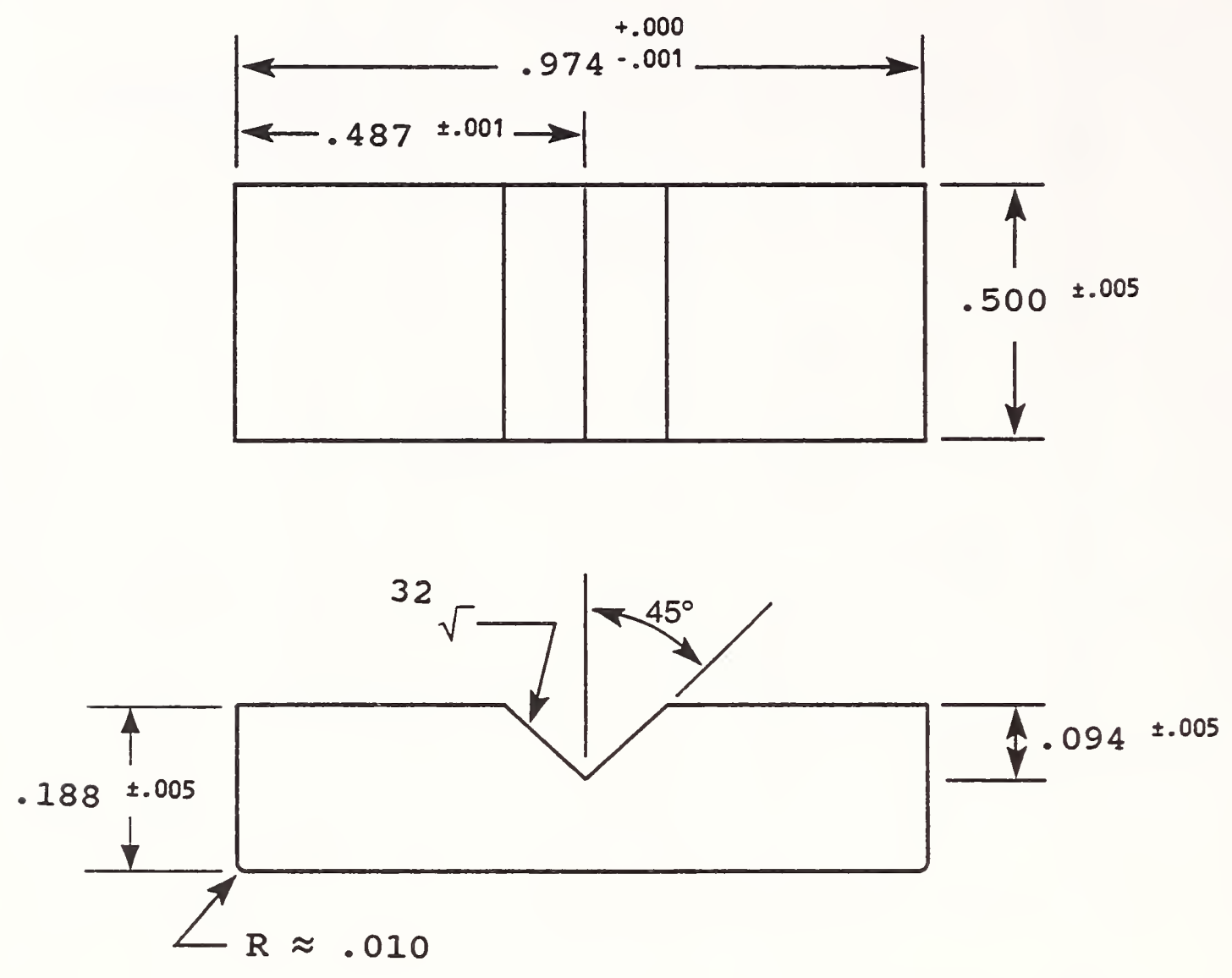

$R_{C}>12$

Figure B3 Three-point adaptor. All dimensions in inches. 


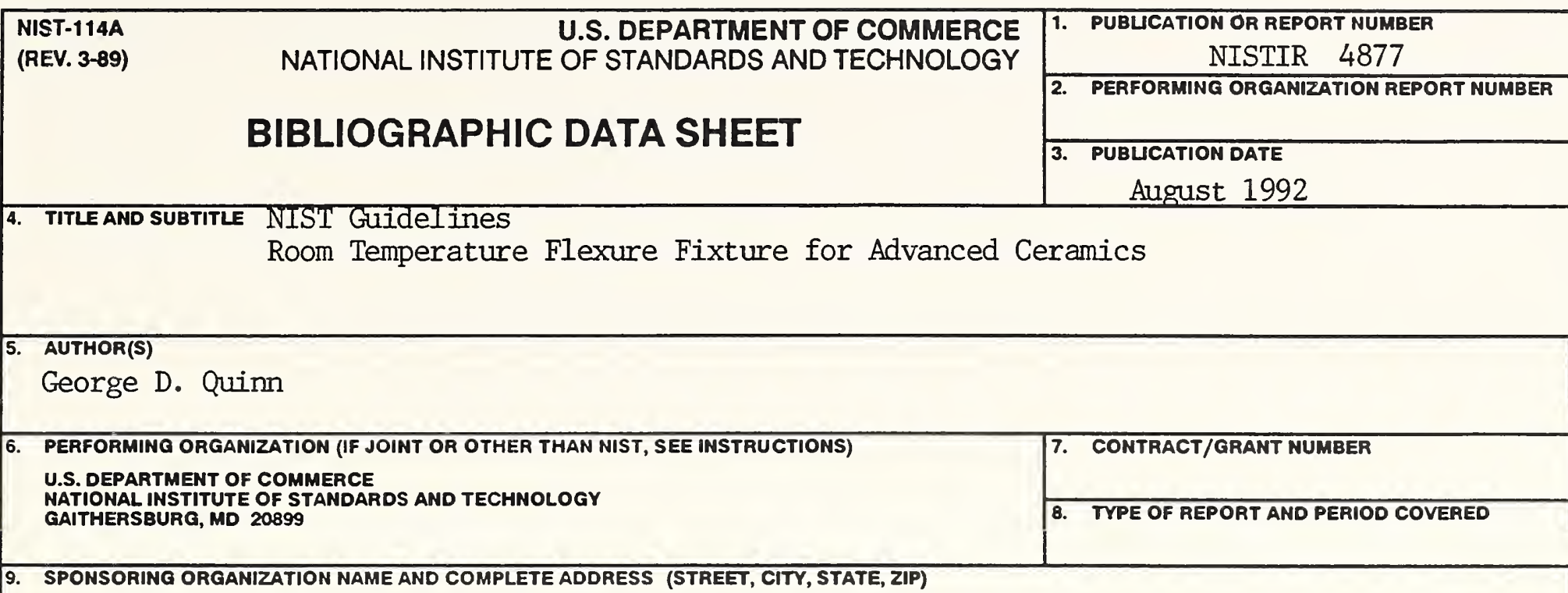

9. SPONSORING ORGANIZATION NAME AND COMPLETE ADDRESS (STREET, CITY, STATE, ZIP)

10. SUPPLEMENTARY NOTES

DOCUMENT DESCRIBES A COMPUTER PROGRAM; SF-185, FIPS SOFTWARE SUMMARY, IS ATTACHED.

11. ABSTRACT (A 200-WORD OR LESS FACTUAL SUMMARY OF MOST SIGNIFICANT INFORMATION. IF DOCUMENT INCLUDES A SIGNIFICANT BIBLOGRAPHY OR LTTERATURE SURVEY, MENTION IT HERE.)

A test fixture for the measurement of the flexure strength of advanced ceramic specimens is presented. The fixture meets the requirements of MIL STD 1942 and ASTM C 1161 and several international standards.

12. KEY WORDS (6 TO 12 ENTRIES; ALPHABETICAL ORDER; CAPITALUE ONLY PROPER NAMES; AND SEPARATE KEY WORDS BY SEMICOLONS) Ceramics; Flexure; Strength; ASTM Standard C 1161; MIL STD 1942 (MR); Set-up; alignment.



FOR OFFICIAL DISTRIBUTION. DO NOT RELEASE TO NATIONAL TECHMICAL INFORMATION SERVICE (NTIS).

ORDER FROM SUPERINTENDENT OF DOCUMENTS, U.S. GOVERNMENT PRINTING OFFICE, WASHINGTON, DC 20402.

ORDER FROM NATIONAL TECHNICAL INFORMATION SERVICE (NTIS), SPRINGFIELD, VA 22161.

14. NUMBER OF PRINTED PAGES

21

15. PRICE

$\mathrm{AO} 3$ 

